\title{
Analisis SWOT Pemasaran Produk Kerupuk Buah di UD. Sukma Kecamatan Takisung Kabupaten Tanah Laut
}

\author{
SWOT Analysis of Fruit Crackers Marketing at UD. Sukma Takisung District, \\ Tanah Laut Regency \\ Raden Rizki Amalia $^{1^{*}}$, Ema Lestari $^{1}$, Meldayanoor $^{1}$ \\ ${ }^{1}$ Jurusan Teknologi Industri Pertanian, Politeknik Negeri Tanah Laut, Jl. A.Yani, Km.6, \\ Desa. Panggung, kec. Pelaihari, kab Tanah Laut, Kalimantan Selatan 70815.Indonesia. \\ Email: ra.amalia.rizki@politala.ac.id
}

Naskah diterima: 12 Agustus 2019; Naskah disetujui : 12 September 2019

\begin{abstract}
UD. Sukma is a fruit cracker processing industry. Problems that occur in UD. Sukma when selling their products yet to identify the marketing mix strategy seen from factor product, location, price and promotion to increase sales of fruit cracker products which generate continuity to its sale. The purpose of this study is to analyze the factors that most influence the marketing mix of fruit crackers internally and externally and determine the marketing strategy of fruit crackers using the SWOT method. The research method used is the identification of marketing mix factors are interviews, questionnaires, IFAS and EFAS factor analysis, and SWOT analysis. Internal factors that most influence strength are the brands used are known to the surrounding community and already have a P-IRT, and have received a halal label from MUI. Weaknesses in internal factors are the packaging used is not attractive, does not have product processing standards that cause inconsistencies in the quality of fruit cracker products, and there is no promotion using social media. Whereas the external factor of opportunity is the timely delivery of products to distributors, promoting products through government agencies. The threat is that the packaging of other similar products is more attractive, there are competitors with the same product at one UD. Sukma selling place and crackers. The products also has been sold to other regions, but with different brand. The right strategy to overcome the problem UD. Sukma is using the Strength-Oppurtunity (SO) strategy, namely the existence of a halal label and P-IRT is the power to take advantage of opportunities, namely by maintaining good relationships with distributors, expanding sales areas, as well as support from the government both through promotion in the form of billboards, and including exhibition to be known to the wider community.
\end{abstract}

Keywords: Fruit Crackers, Marketing, SWOT.

\begin{abstract}
ABSTRAK
UD. Sukma merupakan industri rumah tangga yang bergerak dalam proses pengolahan kerupuk buah di Kecamatan Takisung Kabupaten Tanah Laut. Dalam pemasaran produknya, terdapat beberapa permasalahan yang ada di UD. Sukma diantaranya adalah dalam penjualannya masih menunggu pesanan dari konsumen sehingga penjualan tidak
\end{abstract}


bersifat kontinuitas, produk yang dibeli konsumen diberi merk yang berbeda, dan semakin banyak kompetitor yang memiliki produk yang sama. Oleh karena itu, tujuan dari penelitian ini untuk menganalisis faktor yang paling mempengaruhi pemasaran kerupuk buah secara internal dan eksternal berdasarkan bauran pemasaran serta menentukan strategi pemasaran kerupuk buah menggunakan metode SWOT. Metode penelitian yang digunakan yaitu identifikasi faktor-faktor marketing mix, wawancara, kuisioner, analisis faktor IFAS dan EFAS, dan analisis SWOT. Faktor internal yang paling mempengaruhi kekuatan (strength) yaitu merk yang digunakan sudah diketahui masyarakat sekitar dan sudah memiliki P-IRT, serta sudah mendapatkan label halal dari MUI. Kelemahan dalam faktor internal yaitu kemasan yang digunakan kurang menarik, belum memiliki standar pengolahan produk yang menyebabkan ketidakkonsistenan kualitas produk kerupuk buah, dan tidak adanya promosi menggunakan media sosial. Sedangkan pada faktor eksternal peluang yaitu pengiriman produk tepat waktu pada distributor, mempromosikan produk melalui instansi pemerintah. Adapun ancamannya yaitu kemasan produk lain yang sejenis lebih menarik, terdapat pesaing dengan produk yang sama disatu tempat penjualan dan kerupuk UD. Sukma sudah dijual sampai luar daerah namun merk berbeda. Strategi yang tepat mengatasi pemasalahan UD. Sukma yaitu menggunakan strategi Strength-Opportunity $(\mathrm{SO})$ yaitu dengan adanya label halal dan P-IRT merupakan kekuatan untuk memanfaatkan peluang yaitu dengan mempertahankan hubungan yang baik dengan distributor, memperluas area penjualan, serta adanya dukungan dari pemerintah baik melalui promosi berbentuk baliho, maupun mengikutkan pameran agar dikenal masyarakat luas.

Kata kunci: Kerupuk Buah, Pemasaran, SWOT

\section{PENDAHULUAN}

Sektor pertanian memiliki peranan yang sangat penting dalam pembangunan ekonomi, karena kontribusinya terhadap perekonomian bangsa. Salah satu peranan penting disektor pertanian yaitu sebagai penyedia bahan baku bagi sektor industri. Untuk meningkatkan nilai tambah hasil pertanian tersebut perlu dilakukan usaha pengolahan hasil pertanian (agroindustri) (Febriani et al., 2014).

Industri kerupuk merupakan salah satu industri berbasis rumah tangga yang memiliki potensi cukup bagus untuk dipasarkan. Hal ini didasarkan pada kenyataan bahwa kerupuk merupakan salah satu makanan khas masyarakat Indonesia yang disukai oleh kalangan anak-anak sampai orang dewasa. Kerupuk yang disukai sebagai makanan ringan atau lauk tidak hanya disukai masyakarat perkotaan, tetapi juga merupakan makanan sehari-hari di perdesaan. Kerupuk memiliki rasa yang enak dengan harga yang relatif murah, dan dalam kondisi perekonomian seperti ini terbukti industri tersebut lebih mampu bertahan di tengah kondisi krisis (Khoiriyah et al., 2012).

Salah satu usaha kecil dan menengah berbasis pertanian yang masih eksis saat ini yaitu UD. Sukma yang berlokasi di Jalan Tugu Pancasila RT.07 RW.04 Sumber Makmur 
Kecamatan Takisung Kabupaten Tanah Laut Kalimantan Selatan. Industri rumahan ini mulai beroperasi pada tahun 1996 yang memproduksi kerupuk buah. Adapun kerupuk buah yang diproduksi memiliki 16 varian rasa yaitu rasa buah naga, nanas, nangka, sukun, ubi ungu, sirsak, pisang, jagung, labu dan masih banyak lagi. Pada proses produksinya UD.Sukma mampu membuat kerupuk buah dengan 3 varian rasa dalam satu hari dengan menggunakan $12 \mathrm{~kg}$ bahan baku yang akan menghasilkan $6 \mathrm{~kg}$ kerupuk dan dijual dengan harga Rp.30.000/perbungkusnya.

Berdasarkan informasi yang diperoleh proses produksi di UD.Sukma tidak bersifat kontinuitas atau berkelanjutan, hal ini dikarenakan pada proses penjualannya hanya menunggu pesanan dari konsumen atau tidak dilakukan pemasaran secara kontinuitas baik melalui media sosial maupun media cetak, padahal menurut Putri, Mulyani, dan Satriani (2012) pemasaran merupakan ujung tombak dari serangkaian kegiatan usaha yang bergerak dalam bidang jasa ataupun barang. Pemasaran juga sangat menentukan apakah usaha yang dijalankan mampu bertahan dan menghasilkan laba atau tidak. Produksi dan pemasaran memiliki keterkaitan yang erat. Peningkatan produksi tidak akan berjalan baik bila tidak ada dukungan sistem pemasaran yang dapat menyerap hasil produksi pada tingkat harga yang layak.

Selain itu banyaknya kompetitor yang berasal dari luar Kalimantan, pendistribusi yang mengambil keuntungan dengan menjual kembali produk tersebut ditempat lain dengan merk yang berbeda merupakan permasalahan-permasalahan yang dihadapi UD Sukma. oleh karena itu, perlu dilakukan pengumpulan informasi baik secara internal maupun eksternal usaha menggunakan empat alat marketing mix yaitu produk, harga, lokasi dan promosi. Menurut Kotler dan Keller (2009) empat alat tersebut sangat mempengaruhi pemasaran dan merupakan satu kesatuan bauran untuk mencapai tujuan perusahaan dalam bidang pemasaran dan merupakan pedoman yang mampu diandalkan pemimpin perusahaan dalam kegiatan pemasaran. Dengan adanya informasi tersebut, pemilik usaha dapat mengidentifikasi faktor-faktor internal (kekuatan dan kelemahan) serta faktor-faktor eksternal (peluang dan ancaman) sesuai dengan penggunaan alat marketing mix. Faktor-faktor internal dan eksternal yang telah diidentifikasi dapat dilakukan perumusan strategi melalui analisis SWOT. Menurut Istiqomah dan Andriyanto (2017) analisis SWOT adalah identifikasi berbagai faktor secara sistematis untuk merumuskan strategi. Analisis ini didasarkan pada logika yang dapat memaksimalkan kekuatan (strength) dan peluang (opportunity), namun secara bersamaan dapat meminimalkan kelemahan (weakness) dan ancaman (threats). Dengan demikian, 
perencanaan strategi dapat menganalisa faktor faktor strategi perusahaan (kekuatan, kelemahan, peluang dan ancaman) dalam kondisi saat ini. Oleh karena itu, analisis SWOT digunakan untuk menentukan strategi pemasaran kerupuk buah yang tepat untuk menangani permasalahan-permasalahan tersebut.

\section{METODE PENELITIAN}

\section{Tempat dan Waktu Penelitian}

Penelitian ini dilaksanakan pada bulan Maret sampai dengan bulan Juni 2019, bertempat di UD. Sukma Takisung RT. 07, RW. 04, Kelurahan Sumber Makmur, Kecamatan Takisung, Kabupaten Tanah Laut dan Laboratorium Teknologi Pangan Politeknik Negeri Tanah Laut di Pelaihari Kabupaten Tanah Laut.

\section{Metode Penelitian}

Metode yang digunakan dalam penelitian ini menggunakan analisis SWOT berdasarkan bauran pemasaran. Secara teknis menggunakan metode deskriptif kualitatif terdiri penyajian data, analisis, dan interpretasi data.

\section{Pengumpulan Data}

Teknik pengumpulan data dimulai dari observasi langsung, wawancara, penyebaran kuisioner, serta dokumentasi. Observasi langsung dimulai dari penyediaan bahan baku, proses produksi, pengemasan, sampai dengan pemasaran. Proses wawancara dan kuisioner berhubungan dengan bauran pemasaran (Marketing Mix) yaitu produk, tempat, harga dan promosi. Bauran pemasaran digunakan untuk Adapun yang menjadi responden untuk melakukan wawancara dan kuisioner yaitu serta panelis responden yang dianggap ahli yaitu dari pemilik usaha UD. Sukma, dan 3 konsumen yang loyal (konsumen yang berlangganan lebih dari 3 tahun) sehingga total responden yang digunakan berjumlah 4 orang.

\section{Analisis Data}

Setelah data-data dari hasil wawancara dan kuisioner diperoleh, selanjutnya datadata tersebut dianalisis menggunakan SWOT (Strength, Weakness, Opportunity dan Threat). Faktor-faktor yang telah diperoleh selanjutnya diklasifikasikan antara faktor internal (kekuatan dan kelemahan) dan faktor eksternal (peluang dan ancaman). Tahap selanjutnya diberi pembobotan dari 1,00 hingga 0,00 (dari sangat penting hingga tidak penting) tergantung besarnya dampak faktor tersebut dan pemberian rating dengan skala 4-1 untuk faktor kekuatan dan peluang (kekuatan atau peluang yang besar diberikan nilai 
4 dan yang paling kecil diberikan nilai 1) serta memberi rating skala 1-4 untuk kelemahan dan ancaman (kelemahan atau ancaman yang besar di berikan nilai 1 dan yang paling kecil diberikan nilai 4).

\section{HASIL DAN PEMBAHASAN}

Berdasarkan hasil identifikasi menggunakan analisis SWOT yang terdapat dua faktor yaitu faktor internal, dan faktor eksternal. Faktor internal meliputi dari strength dan weakness yang dapat dilihat pada Tabel 1.

Tabel 1. Matriks IFAS Kerupuk Buah UD. Sukma

\begin{tabular}{|c|c|c|c|c|}
\hline No. & Kekuatan (strength) & Bobot & Rating & Skor \\
\hline 1 & $\begin{array}{l}\text { Merk yang digunakan sudah diketahui masyarakat } \\
\text { disekitar daerah }\end{array}$ & 0,1111111 & 4 & $\overline{0,444444}$ \\
\hline 2 & $\begin{array}{l}\text { Merk yang digunakan sudah terdaftar pada } \\
\text { kepemilikan usaha dagang }\end{array}$ & 0,1111111 & 4 & 0,444444 \\
\hline 3 & $\begin{array}{l}\text { Kemasan yang digunakan sudah memenuhi } \\
\text { standar }\end{array}$ & 0,1018519 & 3,666667 & 0,373457 \\
\hline 4 & Melayani konsumen dengan ramah & 0,1018519 & 3,666667 & 0,373457 \\
\hline 5 & Terdapat label halal dan PI-RT & 0,1111111 & 4 & 0,444444 \\
\hline 6 & Memiliki banyak varian rasa & 0,1018519 & 3,666667 & 0,373457 \\
\hline 7 & Harga yang terjangkau & 0,0925926 & 3,333333 & 0,308642 \\
\hline 8 & Ada potongan harga & 0,0833333 & 3 & 0,25 \\
\hline 9 & $\begin{array}{l}\text { Menjual produk langsung di rumah dengan } \\
\text { menunggu konsumen/ distributor datang membeli }\end{array}$ & 0,0925926 & 3,333333 & 0,308642 \\
\hline \multirow[t]{2}{*}{10} & Produk langsung dijual kekonsumen & 0,0925926 & 3,333333 & 0,308642 \\
\hline & TOTAL & 1 & 36 & 3,62963 \\
\hline No. & Kelemahan (weakness) & Bobot & Rating & Skor \\
\hline 1 & $\begin{array}{l}\text { Kemasan yang digunakan belum cukup menarik } \\
\text { perhatian pembeli }\end{array}$ & 0,136364 & 1 & 0,136364 \\
\hline 2 & Belum memiliki standar pengolahan produk & 0,136364 & 1 & 0,136364 \\
\hline 3 & $\begin{array}{l}\text { Belum ada kemampuan untuk menjual sendiri } \\
\text { produk keluar }\end{array}$ & 0,272727 & 2 & 0,545455 \\
\hline 4 & Belum ada promosi lewat media cetak & 0,272727 & 2 & 0,545455 \\
\hline \multirow[t]{2}{*}{5} & Belum ada pemasaran lewat sosial media & 0,181818 & 1,333333 & 0,242424 \\
\hline & TOTAL & 1 & 7,333333 & 1,606061 \\
\hline
\end{tabular}

Tabel 3. Matrik EFAS Kerupuk Buah UD. Sukma

\begin{tabular}{llllll}
\hline No & Peluang (oppurtuniti) & Bobot & Rating & Skor \\
\hline $\mathbf{1}$ & $\begin{array}{l}\text { Pengiriman produk tepat waktu pada } \\
\text { distributor }\end{array}$ & 0,4736842 & 3 & 1,421053 \\
$\mathbf{2}$ & $\begin{array}{l}\text { Mempromosikan produk melalui kerjasama } \\
\text { dengan Dinas Pemerintah } \\
\text { TOTAL }\end{array}$ & 0,5263158 & 3,333333 & 1,754386 \\
& 1 & 6,333333 & 3,175439 \\
\hline No & Ancaman (threath) & Bobot & Ranting & Skor \\
\hline
\end{tabular}




\begin{tabular}{lllll}
\hline $\mathbf{1}$ & $\begin{array}{l}\text { Ada produk dengan merk yang hampir } \\
\text { sama }\end{array}$ & 0,142857 & 1,666667 & 0,238095 \\
$\mathbf{2}$ & $\begin{array}{l}\text { Kemasan produk lain sejenis lebih menarik } \\
\mathbf{3}\end{array}$ & 0,085714 & 1 & 0,085714 \\
$\mathbf{4}$ & $\begin{array}{l}\text { Sulitnya mendapatkan ijin BPOM } \\
\text { baitnya mendapatkan bahan baku yang }\end{array}$ & 0,142857 & 1,666667 & 0,238095 \\
$\mathbf{5}$ & $\begin{array}{l}\text { Ada produk yang sama dengan harga yang } \\
\text { sama }\end{array}$ & 0,142857 & 1,666667 & 0,238095 \\
$\mathbf{6}$ & $\begin{array}{l}\text { Terdapat pesaing dengan produk yang sama } \\
\text { disatu tempat penjualan }\end{array}$ & 0,085714 & 1 & 0,0867674 \\
$\mathbf{7}$ & $\begin{array}{l}\text { Produk belum tersedia dimarket-market } \\
\text { ternama }\end{array}$ & 0,171429 & 2 & 0,342857 \\
$\mathbf{8}$ & $\begin{array}{l}\text { Produk sudah dijual sampai luar daerah } \\
\text { dengan merk berbeda }\end{array}$ & 0,085714 & 1 & 0,085714 \\
\hline TOTAL & 1 & 11,66667 & 1,552381 \\
\hline
\end{tabular}

Berdasarkan Tabel 1 hasil skoring tertinggi faktor-faktor yang sangat mempengaruhi bauran pemasaran secara internal yaitu terdapat 3 faktor strength (kekuatan) pada faktor internal yaitu adalah merk yang digunakan sudah diketahui masyarakat disekitar daerah karena kerupuk buah UD. Sukma sudah menjual produknya dari tahun 1996 yang memiliki nilai bobot 0,1018519, rating 3,666667 dan skor 0,373457 . Selain itu faktor kekuatan lainnya yaitu sudah terdaftar pada kepemilikan usaha dagang sejak tahun 2015, dan faktor kekuatan terakhir yaitu sudah mendapatkan label halal dari MUI (Majelis Ulama Indonesia) sejak tahun 2018 dan P-IRT dari Dinas Kesehatan. Faktor kekuatan ini sependapat dengan pernyataan Lasander (2013) yang menjelaskan bahwa merk memiliki peran yang khusus dalam benak konsumen, dimana umumnya konsumen memandang merk sebagai bagian penting dari produk. Adanya atribut produk tersebut akan mendorong konsumen, untuk membeli produk tersebut karena percaya akan kemampuan merk dalam memuaskan kebutuhan konsumen. Begitu juga dengan adanya label halal dan P-IRT, produk dapat dengan mudah menembus pasar tradisional atau modern. Hal ini sesuai dengan pernyataan Amalia dan Hairiyah (2019) menjelaskan bahwa P-IRT dapat digunakan untuk memperluas pemasaran produk.

Pada faktor weakness (kelemahan) terdapat 3 faktor permasalahan yang menjadi kelemahan yaitu kemasan yang digunakan belum cukup menarik perhatian konsumen sebab kemasan yang digunakan hanya berupa kemasan standart berupa plastik tebal yang ditetapkan oleh pemerintah, sedangkan konsumen menginginkan kemasan yang lebih inovatif dan modern. Faktor kelemahan ini sesuai dengan pendapat Resmi dan Wismiarsi (2015) yang menjelaskan bahwa kemasan yang menarik akan meninggalkan kesan yang baik dan akan mempengaruhi persepsi konsumen terhadap sebuah produk. Selain itu belum memiliki standar pengolahan produk yang menyebabkan ketidakkonsistenan 
kualitas produk kerupuk buah padahal menurut Badan Pom (2017) untuk menghasilkan produk yang bermutu salah satu langkah pengendalian kualitasnya yaitu dengan melakukan penetapan tehadap komposisi dan formulasi bahan.

Permasalahan lain pada faktor kelemahan yaitu tidak adanya promosi menggunakan media sosial, padahal di zaman teknologi yang berkembang sangat pesat seperti sekarang ini promosi melalui media sosial merupakan sebuah peluang untuk meningkatkan omset penjualan padahal menurut Nuraeni dan Harnanik (2017) promosi merupakan salah satu faktor penentu keberhasilan suatu program pemasaran. Sebagus apapun kualitas suatu produk, bila konsumen belum pernah mendengarkannya dan tidak yakin bahwa produk itu akan berguna bagi konsumen, maka konsumen tidak akan pernah membelinya.

Selain faktor internal, terdapat juga faktor eksternal yang meliputi Opportunity (peluang) dan Threath (ancaman). Berdasarkan Tabel 2, terdapat dua faktor Opportunity (peluang) yang ada pada faktor eksternal, yaitu pengiriman produk tepat waktu pada distributor dengan skor 1,421053 dan mempromosikan produk melalui kerjasama dengan dinas pemerintah yang memiliki skor sebesar 1,754386. Pengiriman produk kepada distributor harus tepat waktu yang telah disepakati merupakan peluang yag besar bagi produsen untuk mendapatkan kepercayaan dari konsumen, sebab pada umumnya konsumen sangat mementingkan kualitas kinerja dari produsen dalam mengelola produk mereka, dengan cara mengirim produk tepat waktu kepada distributor maka akan menaruh kepercayaan kepada produsen sehingga pemesan produk akan terus berlanjut, dan menurut Bahrudin dan Zuhro (2015) jika konsumen tidak dipuaskan atau sudah tidak percaya dengan sebuah produk, konsumen cenderung beralih merk serta mengajukan keberatan pada produsen, pengecer atau bahkan menceritakannya kepada konsumen lain.

Promosi produk melalui instansi pemerintah juga sangat penting untuk pengenalan produk secara luas, cara yang biasanya dilakukan pemerintah dalam mempromosikan sebuah produk UKM (Usaha Kecil Menengah) adalah dengan memperkenalkan produk ke masyarakat luas melalui acara-acara bazar UKM didaerah atau di luar daerah dan memasang sebuah sepanduk bergambarkan produk tersebut di berbagai kegiatan pengenalan produk UKM. Cara promosi produk seperti ini merupakan peluang yang sangat efektif dalam mengenalkan produk tersebut kepada masyarakat luas. Matriks EFAS juga menunjukkan tiga faktor treath (ancaman) bagi Kerupuk Buah UD. Sukma yaitu kemasan produk lain yang sejenis lebih menarik dengan harga yang sama, terdapat pesaing dengan produk yang sama disatu tempat penjualan dan produk kerupuk UD. 
Sukma sudah dijual sampai luar daerah namun merk berbeda yang memiliki nilai skor 0,085714 . Kemasan produk lain yang sejenis lebih menarik perhatian konsumen dari pada kemasan produk sendiri adalah sebuah ancaman yang besar bagi produk kerupuk buah UD.Sukma. Kemasan atau penampilan dari sebuah produk adalah hal pertama yang dilihat konsumen setelah kualitas dari produk tersebut dan sebuah daya tarik yang kuat untuk membuat konsumen membeli suatu produk. Ancaman ini harus sesegera mungkin disadari dan dihindari oleh produsen agar mampu bersaing dipasaran dengan produk lain dan membuat konsumen menjadi tertarik untuk membeli produk tersebut (Yanti, Delvy, dan Permata., 2016)

Terdapat pesaing dengan produk yang sama adalah ancaman yang serius untuk semua pemilik suatu usaha pangan khususnya untuk usaha kerupuk buah. Kualitas produk sangat berperan penting, konsumen akan mengenal kualitas produk yang terbaik yang akan terus mereka beli, sebaliknya kualitas produk yang jelek akan membuat konsumen tidak akan membeli kembali sehingga dalam ancaman seperti ini produsen harus mempertahankan dan meningkatkan kualitas produk mereka agar konsumen tetap loyal terhadap produk tersebut. Produk telah dijual diluar daerah dengan merk yang berbeda maksudnya adalah produk kerupuk buah UD Sukma dibeli dan dijual kembali tetapi dikemas dan diberi merk yang berbeda dengan produk semula dan telah dijual keluar daerah. Ancaman seperti ini sangat tidak menguntungkan bagi produsen aslinya, karena produk mereka terkenal didaerah lain tetapi dengan merk yang berbeda.

Berdasarkan Tabel 1 matrik IFAS kerupuk buah, maka didapatkan hasil total skor faktor kekuatan (strength) yaitu 3,62963 dan untuk kelemahan (weakness) yaitu 1,606061. Sementara pada Tabel 2 Matrik EFAS didapatkan hasil total skor faktor peluang (opportunity) yaitu 3,175439 dan untuk faktor ancaman (threath) yaitu 1,552381. Dari hasil tersebut, kemudian digambarkan dalam diagram kartesius SWOT, dimana faktor kekuatan dan peluang diberi nilai positif $(+)$, serta faktor kelemahan dan ancaman diberi nilai negatif (-) yang dapat dilihat pada Gambar 1. 


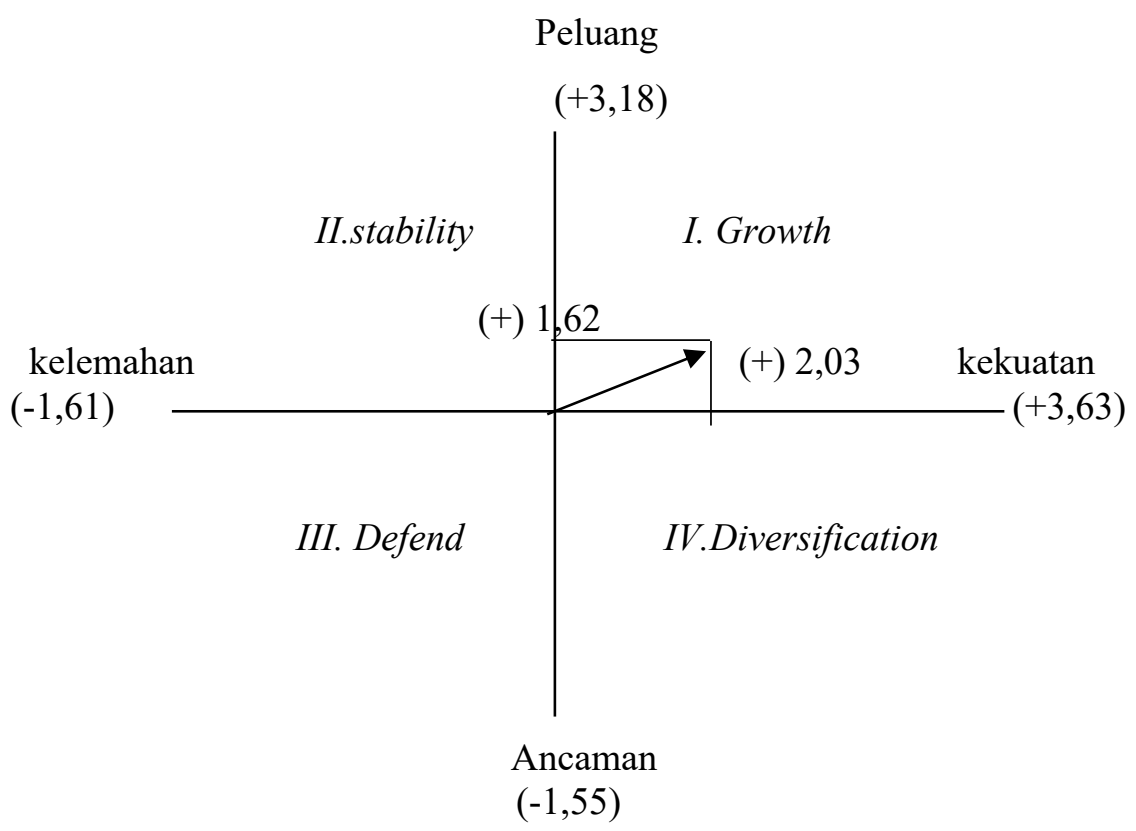

Gambar 1. Diagram Kartesius SWOT Kerupuk Buah UD.Sukma

Berdasarkan diagram kartesius SWOT yang dapat dilihat pada Gambar 1 menunjukkan UD. Sukma berada pada Kuadran I yang berarti berdasarkan matriks TOWS strategi yang digunakan adalah strategi Strength-Oppurtuniti (SO) yang disebut juga strategi Growth. Strategi SO yaitu strategi yang dihasilkan dari suatu cara pandang bahwa perusahaan atau unit bisnis tertentu dapat menggunakan kekuatan (strengths) yang mereka dimiliki guna memanfaatkan berbagai peluang (opportunities) (Anggraeni et al., 2017). Adapun strategi SO untuk kerupuk buah UD Sukma yaitu dengan adanya label halal dan P-IRT merupakan sebuah kekuatan untuk memanfaatkan peluang yaitu dengan mempertahankan hubungan yang baik dengan distributor, memperluas area penjualan, ditambah lagi dengan adanya dukungan pemerintah baik melalui promosi berbentuk baliho, maupun mengikutkan kepameran-pameran agar dikenal masyarakat luas. Hal ini sesuai dengan pernyataan Anggraeni et al (2017) yang menjelaskan bahwa mempertahankan hubungan kerja sama yang baik serta harmonis antara pemilik, karyawan dan distributor merupakan strategi yang tepat untuk meningkatkan pendapatan. Hal ini yang dialami Keripik Tempe "Amel" dengan toko distributornya yang bernama "Rohani" yang sudah menjalin kerja sama cukup lama yakni selama 12 tahun dimulai dari tahun 2004, setahun setelah Keripik Tempe “Amel” berdiri. Selain itu menurut Khoiriyah et al (2012) menjelaskan dengan adanya surat izin usaha dari dinas yang terkait maka pemasaran produk kerupuk terasi yang dihasilkan dapat diperluas karena masyarakat 
tidak ragu untuk membeli produk tersebut serta mengikuti pameran untuk mempromosikan produk yang dihasilkan agar dikenal di masyarakat luas.

\section{KESIMPULAN}

Berdasarkan hasil analisis SWOT yang telah dilakukan di UD. Sukma pada penjualan kerupuk buahnya dapat disimpulkan bahwa strategi yang tepat mengatasi pemasalahan di UD. Sukma ini menggunakan strategi Strength-Opportunity (SO) yang disebut juga strategi Growth yaitu dengan adanya label halal dan P-IRT merupakan sebuah kekuatan untuk memanfaatkan peluang yaitu dengan mempertahankan hubungan yang baik dengan distributor, memperluas area penjualan, ditambah lagi dengan adanya dukungan pemerintah baik melalui promosi berbentuk spanduk, maupun mengikuti pameran-pameran agar dikenal masyarakat luas.

\section{UCAPAN TERIMAKASIH}

Terimakasih kami ucapkan kepada Kemenristek Dikti atas pendanaan hibah penelitian dosen pemula Tahun 2019 sebagai sumber dana utama dalam melaksanakan penelitian ini dengan Nomor Kontrak 043/SP2H/LT/DRPM/2019.

\section{DAFTAR PUSTAKA}

Amalia, Rizki R, Nina Hairiyah. 2019. "Strategi Pemasaran Produk Bepang UD. Cap Bunga Kecamatan Pelaihari Kabupaten Tanah Laut." Jurnal Teknologi AgroIndustri 6(1):51-60.

Anggraeni, Pratiwi, Sunarti, and M. Kholid Mawardi. 2017. "Analisis Swot Pada UMKM Keripik Tempe Amel Malang Dalam Rangka Meningkatkan Daya Saing Perusahaan.” Jurnal Administrasi Bisnis 43(1):104-13.

Badan Pom. 2017. "Produksi Pangan Untuk Industri Rumah Tangga Kerupuk Amplang." Direktorat Pemberdayaan Masyarakat Dan Pelaku Usaha Deputi Bidang Pengawasan Pangan Olahan Badan Pengawas Obat Dan Makanan, Jakarta Pusat, Indonesia.

Bahrudin, Muhammad and Siti Zuhro. 2015. "Pengaruh Kepercayaan dan Kepuasan Pelanggan Terhadap Loyalitas Pelanggan.” Jurnal Bisnis Dan Manajemen Islam $3(1): 1-17$. 
Febriani, Reby, Roza Yulida, and Kausar. 2014. "Persepsi dan Minat Petani Nenas Terhadap Usaha Agroindustri Nenas Di Desa Kualu Nenas Kecamatan Tambang Kabupaten Kampar.” Jurnal Jom Faperta 1(2).

Istiqomah and Irsad, Andriyanto. 2017. "Analisis SWOT dalam Pengembangan Bisnis (Studi pada sentra jenang di Desa Wisata Kaliputu Kudus)". Jurnal Bisnis dan Manajemen Islam 5(2): 363-382.

Khoiriyah, Nur R., Aminah H. M. Ariyani, and Elys Fauziyah. 2012. "Strategi Pengembangan Agroindustri Kerupuk Terasi(Studi Kasus Di Desa Plosobuden, Deket, Lamongan)." Jurnal Sosial Ekonomi Dan Kebijakan Pertanian 1(2):13548.

Kotler, Philip and Kevin Lane Keller. 2009. "Manajemen Pemasaran, Terjemah Benyamin Molan. Edisi 13. PT. Indeks. Jakarta.

Lasander, Christian. 2013. "Citra Merek, Kualitas Produk, Dan Promosi Pengaruhnya Terhadap Kepuasan Konsumen Pada Makanan Tradisional." Jurnal EMBA 1(3):284-93.

Nuraeni, Leni and Harnanik. 2017. "Strategi Bauran Pemasaran Usaha Kecil Keripik Bhineka Di Desa Belendung Kecamatan Purwadadi Kabupaten Subang.” Economic Education Analysis Journal 6(2):647-55.

Putri, Dindy Darmawanti, Altri Mulyani, and Ratna Satriani. 2012. "Strategi Pemasaran Keripik Pisang Dalam Rangka Mencapai Ketahanan Pangan Di Kecamatan Cilongok, Kabupaten Banyumas." SEPA 8(2):162-67.

Resmi, Nanda and Tri Wismiarsi. 2015. "Pengaruh Kemasan Dan Harga Pada Keputusan Pembelian Minuman Isotonik.” Jurnal Manajemen Dan Bisnis Sriwijaya 13(1):120.

Yanti, Delvi and Deivy Andhika Permata. 2016. "Pemberdayaan Masyarakat Tani Melalui Pengembangan Produk Olahan Ikan Di Nagari Tarung-Tarung , Kecamatan Rao , Kabupaten Pasaman , Sumatera Barat.” Jurnal Ilmiah Pengabdian Kepada Masyarakat 2(2):73-80. 